\title{
Desalination and Reuse of High-Salinity Shale Gas Produced Water: Drivers, Technologies, and Future Directions
}

\author{
Devin L. Shaffer, Laura H. Arias Chavez, Moshe Ben-Sasson, Santiago Romero-Vargas Castrillón, \\ Ngai Yin Yip, and Menachem Elimelech* \\ Department of Chemical and Environmental Engineering, Yale University, P.O. Box 208286, New Haven, Connecticut 06520-8286, \\ United States
}

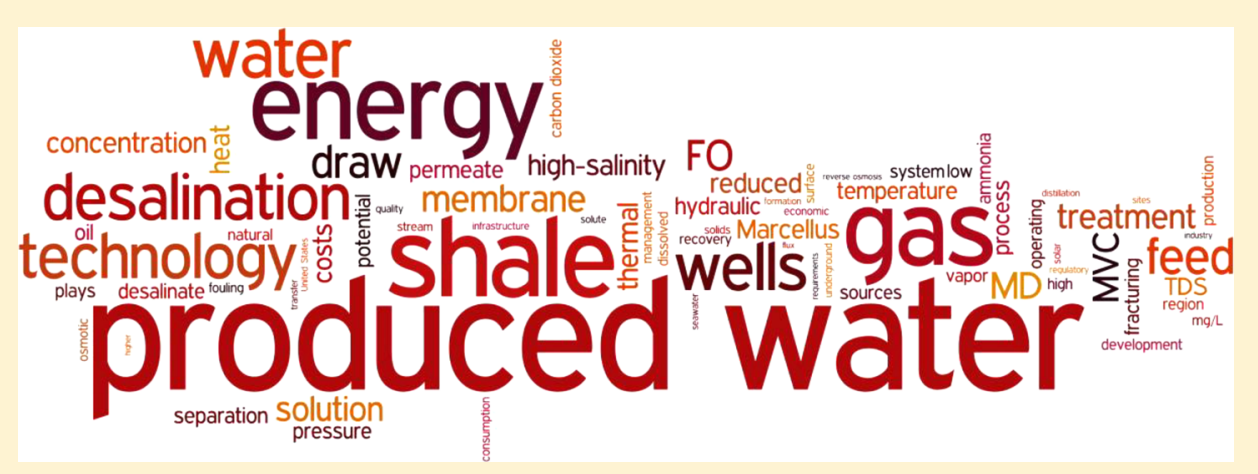

ABSTRACT: In the rapidly developing shale gas industry, managing produced water is a major challenge for maintaining the profitability of shale gas extraction while protecting public health and the environment. We review the current state of practice for produced water management across the United States and discuss the interrelated regulatory, infrastructure, and economic drivers for produced water reuse. Within this framework, we examine the Marcellus shale play, a region in the eastern United States where produced water is currently reused without desalination. In the Marcellus region, and in other shale plays worldwide with similar constraints, contraction of current reuse opportunities within the shale gas industry and growing restrictions on produced water disposal will provide strong incentives for produced water desalination for reuse outside the industry. The most challenging scenarios for the selection of desalination for reuse over other management strategies will be those involving highsalinity produced water, which must be desalinated with thermal separation processes. We explore desalination technologies for treatment of high-salinity shale gas produced water, and we critically review mechanical vapor compression (MVC), membrane distillation (MD), and forward osmosis (FO) as the technologies best suited for desalination of high-salinity produced water for reuse outside the shale gas industry. The advantages and challenges of applying MVC, MD, and FO technologies to produced water desalination are discussed, and directions for future research and development are identified. We find that desalination for reuse of produced water is technically feasible and can be economically relevant. However, because produced water management is primarily an economic decision, expanding desalination for reuse is dependent on process and material improvements to reduce capital and operating costs.

\section{INTRODUCTION}

The application of horizontal drilling and hydraulic fracturing techniques has unlocked a vast natural gas resource from shale formations. With the addition of shale gas reserves, estimated global technically recoverable gas reserves have increased by over $40 \%$ since $2010,{ }^{1}$ prompting the International Energy Agency to speculate about a "Golden Age of Gas" that will be characterized by high energy demand in urbanizing regions and low-cost, widely available shale gas resources. ${ }^{2}$ In the United States, where shale gas production techniques were developed, shale gas is recognized as a "game changer" in the natural gas market, ${ }^{3}$ and the U.S. is projected to move from a net natural gas importer to become a natural gas exporter. ${ }^{3}$

The rapid development of shale gas in the United States has been controversial. Proponents advocate for shale gas production as an economic boon ${ }^{4}$ and a potential bridge to a low-carbon future. ${ }^{5}$ Opponents contend that the potential for drinking water contamination from shale gas wells, ${ }^{6,7}$ negative environmental impacts of produced water management, ${ }^{8}$ and potential for leakage of methane, ${ }^{9}$ a potent greenhouse gas, outweigh any benefits. Some states in the United States ${ }^{10,11}$ and other countries ${ }^{2}$ maintain effective moratoriums on drilling and development of shale gas wells.

Managing the produced water that is associated with shale gas is one of the biggest challenges for preserving the favorable economics of shale gas development and protecting human health and the environment. ${ }^{12,13}$ Growing restrictions on

Received: May 2, 2013

Revised: July 18, 2013

Accepted: July 25, 2013

Published: July 25, 2013 


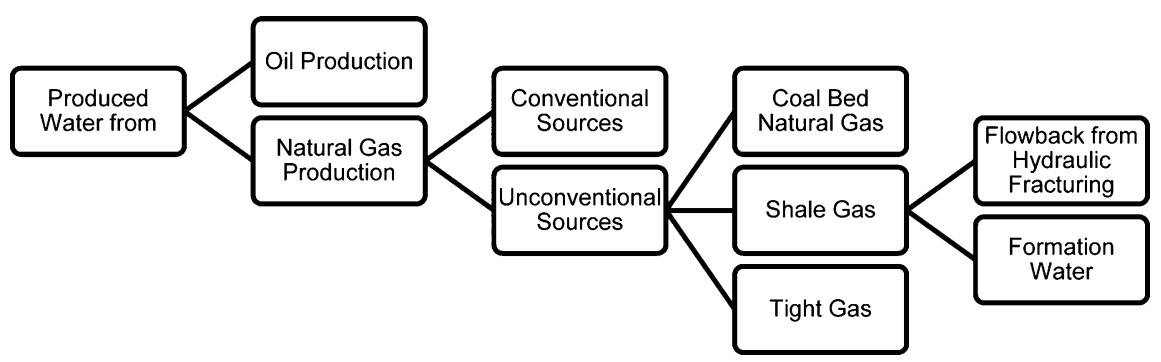

Figure 1. Schematic illustrating the categorization of shale gas as one type of unconventional natural gas resource and indicating the two components of shale gas produced water: flowback and formation water.

produced water disposal and eventual contraction of reuse opportunities within the shale gas industry will ultimately move the industry toward desalination of produced water, but highsalinity produced water is especially challenging and energyintensive to treat. Technological advances in shale gas produced water desalination, similar to the advances in hydraulic fracturing that facilitated the development of the shale gas industry, must be developed to promote expanded reuse opportunities that require higher quality water. ${ }^{14}$ The Barnett shale region in Texas served as a testing ground for the refinement and commercialization of horizontal drilling and hydraulic fracturing techniques that are now being applied worldwide. ${ }^{15}$ Similarly, the unique produced water characteristics, shale formation geology, infrastructure, and regulatory environment of the Marcellus shale region in the eastern United States are promoting innovation in produced water reuse. The produced water management constraints of the Marcellus shale region will eventually drive Marcellus shale gas producers, and those in similarly constrained regions, to desalinate produced water to broaden its potential for reuse.

We critically review desalination technologies that may be implemented at shale gas well sites or centralized treatment facilities to enable reuse of high-salinity produced water outside of the shale gas industry. This "external reuse" requires much higher water quality than current "internal reuse" practices that recycle produced water within the shale gas industry for subsequent hydraulic fracturing operations. Produced water management in the Marcellus shale region is highlighted to illustrate the myriad considerations that influence produced water treatment decisions and the anticipated future application of desalination technologies. Mechanical vapor compression, membrane distillation, and forward osmosis are reviewed as the three desalination technologies best suited for use under the incentives and constraints represented by the Marcellus shale region. The relative energy requirements and potential energy sources for the three technologies are assessed and compared.

\section{PRODUCED WATER-A SHALE GAS BYPRODUCT}

Categorization and Components of Shale Gas Produced Water. Produced water is water from underground formations that is brought to the surface during oil or gas production, and it is the largest volume waste stream associated with this production. ${ }^{16}$ Shale gas production is the extraction of natural gas from shale plays, which are hydrocarbon-rich, lowpermeability shale formations within known hydrocarbonproducing basins. Shale gas is considered an unconventional natural gas resource because the shale serves as both the source and the reservoir for the gas. In contrast, conventional sources are relatively high-permeability formations that are capped with impermeable barriers. Natural gas from sources beneath or adjacent to the formation accumulates beneath these impermeable caps. ${ }^{17}$

The extraction of shale gas is facilitated by horizontal drilling and hydraulic fracturing techniques that are able to access large areas of the shale formation and increase the shale permeability to enable gas to flow. ${ }^{17}$ Shale gas produced water consists of both formation water and flowback from hydraulic fracturing. Flowback returns to the surface during the initial weeks of well pumping after hydraulic fracturing has occurred, and formation water is extracted over the lifetime of the well. ${ }^{17}$ Figure 1 illustrates the categorization of shale gas and the components of shale gas produced water.

The quantity and quality of produced water from shale gas wells vary by shale gas play, by well location within a shale play, and over the lifetime of the well. The highest rate of flowback occurs immediately after well pumping begins and diminishes over time. ${ }^{12}$ Drilling and hydraulically fracturing a shale gas well is estimated to require approximately $2-4$ million gallons of water (48 000-95000 barrels (bbl), 8000-15000 m m. $^{17}$ Historical data show that median water use for developing a shale gas well in Texas is $2.8-5.7$ million gallons (67000$140000 \mathrm{bbl}, 11000-22000 \mathrm{~m}^{3}$ ), depending on the specific shale play, ${ }^{18}$ and the median volume of water used for hydraulically fracturing a horizontal well in Oklahoma is 3.0 million gallons $\left(71000 \mathrm{bbl}, 11000 \mathrm{~m}^{3}\right) .{ }^{19}$ In the Marcellus shale region, drilling and hydraulically fracturing a horizontal well requires an estimated $2-7$ million gallons (48 000$\left.170000 \mathrm{bbl}, 8000-27000 \mathrm{~m}^{3}\right){ }^{13}$ The percentage of this initial volume that is returned to the surface as flowback is specific to the well and has been estimated as $8-15 \%,{ }^{14} 10-40 \%,{ }^{12} 9-$ $53 \%{ }^{13}$ and $30-70 \% .{ }^{17}$ The remaining volume is considered formation water, though differentiating flowback from formation water is difficult because fracturing fluids become more similar to formation water the longer they remain in contact with the formation. ${ }^{17}$

Long-term produced water volumes from shale gas wells vary across different shale plays and ultimately depend on the lifetime of the shale gas well. Shale gas produced water generation can be compared between shale plays using the metric of gallons of water produced per million cubic feet of gas produced (gal/MMcf). One shale gas producer reports longterm produced water (which we assume to be formation water) estimates of $200-1000 \mathrm{gal} / \mathrm{MMcf}$ in the Eagle Ford, Haynesville, and Fayetteville shale plays; more than $1000 \mathrm{gal} / \mathrm{MMcf}$ in the Barnett shale play; and only approximately 25-200 gal/ MMcf in the Marcellus shale play. ${ }^{20}$ A recent analysis of the first 4 years of production from Marcellus shale gas wells in Pennsylvania showed the average brine (formation water) production to be approximately $700 \mathrm{gal} / \mathrm{MMcf}^{14}$ 


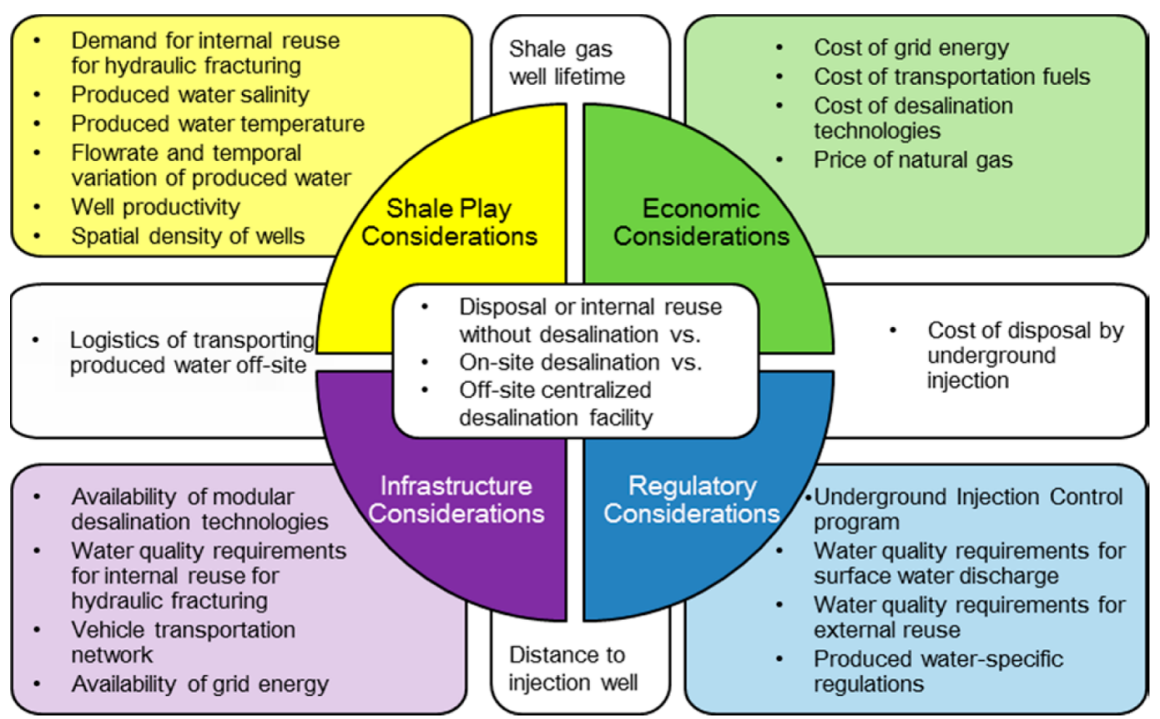

Figure 2. Interrelated shale play, economic, regulatory, and infrastructure considerations that influence decisions about produced water management via disposal or internal reuse without desalination versus external reuse, which requires produced water desalination either on-site at the well location or at an off-site centralized facility.

\section{Current Produced Water Management Practices in} the United States. Management of produced water is primarily an economic decision ${ }^{21}$ that is directly influenced by the produced water volume and quality, state and federal regulations, available infrastructure, and characteristics of the specific shale play. Figure 2 illustrates the considerations that affect produced water treatment and disposal decisions. The vast majority of produced water in the U.S. is injected underground via the federal Underground Injection Control program, either to maintain pressure in active formations or for disposal. A survey of oil and gas produced water management practices in the United States in 2007 found that more than $98 \%$ of produced water from onshore oil and gas wells is injected underground. ${ }^{16}$ Underground injection will remain an important component of produced water management, even when desalination is employed for external reuse, because it is a disposal mechanism for the concentrated brine stream resulting from any desalination process.

A small fraction of produced water is discharged to surface water, managed by evaporation ponds, or beneficially reused outside of the industry, ${ }^{16}$ for example in livestock watering or irrigation. $^{22}$ These management practices are typically employed only for high-quality produced water with relatively low dissolved solids concentrations, such as in the Big Horn and Powder River Basins of Montana and Wyoming in the United States. ${ }^{22}$ Direct beneficial reuse of produced water in the U.S. is limited by the Clean Water Act to livestock watering or agricultural uses west of the 98th meridian. ${ }^{23}$

Reuse of produced water for shale gas well development (which we will term "internal reuse") is a growing trend, especially where this reuse is economically advantageous, such as in the Marcellus shale region. Successful internal reuse can reduce the fresh water demands for subsequent hydraulic fracturing operations as well as reduce produced water disposal costs. Internal reuse has expanded as shale gas producers have experimented with reusing produced water that has not been desalinated. $^{21}$ For internal reuse, produced water is often blended with fresh water to reduce the high dissolved solids concentration and mitigate its effects on fluid viscosity. ${ }^{20}$ Internal reuse of produced water with elevated concentrations of dissolved solids must also consider factors such as corrosion of well materials, ${ }^{18}$ scaling that impedes gas flow to the well, ${ }^{14}$ and the effects of varying salinity on clay swelling within the formation. $^{14}$

Marcellus Shale Region Illustrates Drivers for Produced Water Desalination and Reuse. The Marcellus shale play is by far the largest shale gas reservoir in the United States, with estimated technically recoverable resources of approximately 140 trillion cubic feet of natural gas (140 Tcf or 4.0 $\left.\mathrm{Tm}^{3}\right){ }^{3}$. Two "sweet spots" of drilling activity are northeastern and southwestern Pennsylvania, and the number of Marcellus shale well permits issued by the state has increased dramatically since $2007 .^{24}$ The Marcellus play also underlies portions of neighboring New York, where an effective moratorium on highvolume hydraulic fracturing operations was instituted in 2008 and was recently extended to allow for additional health impact studies. $^{10}$

Management of high-salinity produced water from the Marcellus shale in Pennsylvania, which ranges in total dissolved solids concentration from 8000 to $360000 \mathrm{mg} / \mathrm{L}$ with an average concentration of approximately $190000 \mathrm{mg} / \mathrm{L},{ }^{25}$ has evolved with changing regulations and the growth of the shale gas industry. During the period 2008-2011, the primary disposal method has shifted from municipal wastewater treatment facilities to industrial wastewater treatment facilities to underground injection wells and reuse for subsequent well development. ${ }^{14}$ Recent data from Pennsylvania show that internal reuse is now the most common produced water management practice, and in $2012,90 \%$ of produced water was reused for hydraulic fracturing operations. ${ }^{13}$ The shift away from treatment facilities that ultimately discharge to surface water in favor of other produced water management strategies has been regulatory-driven in response to concerns about increasing total dissolved solids (TDS) concentrations in the receiving waters. In 2008, TDS concentrations in the Monongahela River rose to $900 \mathrm{mg} / \mathrm{L}$, almost double the established water quality standard of $500 \mathrm{mg} / \mathrm{L}{ }^{26}$ The increase has been partly attributed to shale gas produced water disposal at municipal wastewater treatment facilities, which are not equipped to remove dissolved solids. The high TDS 


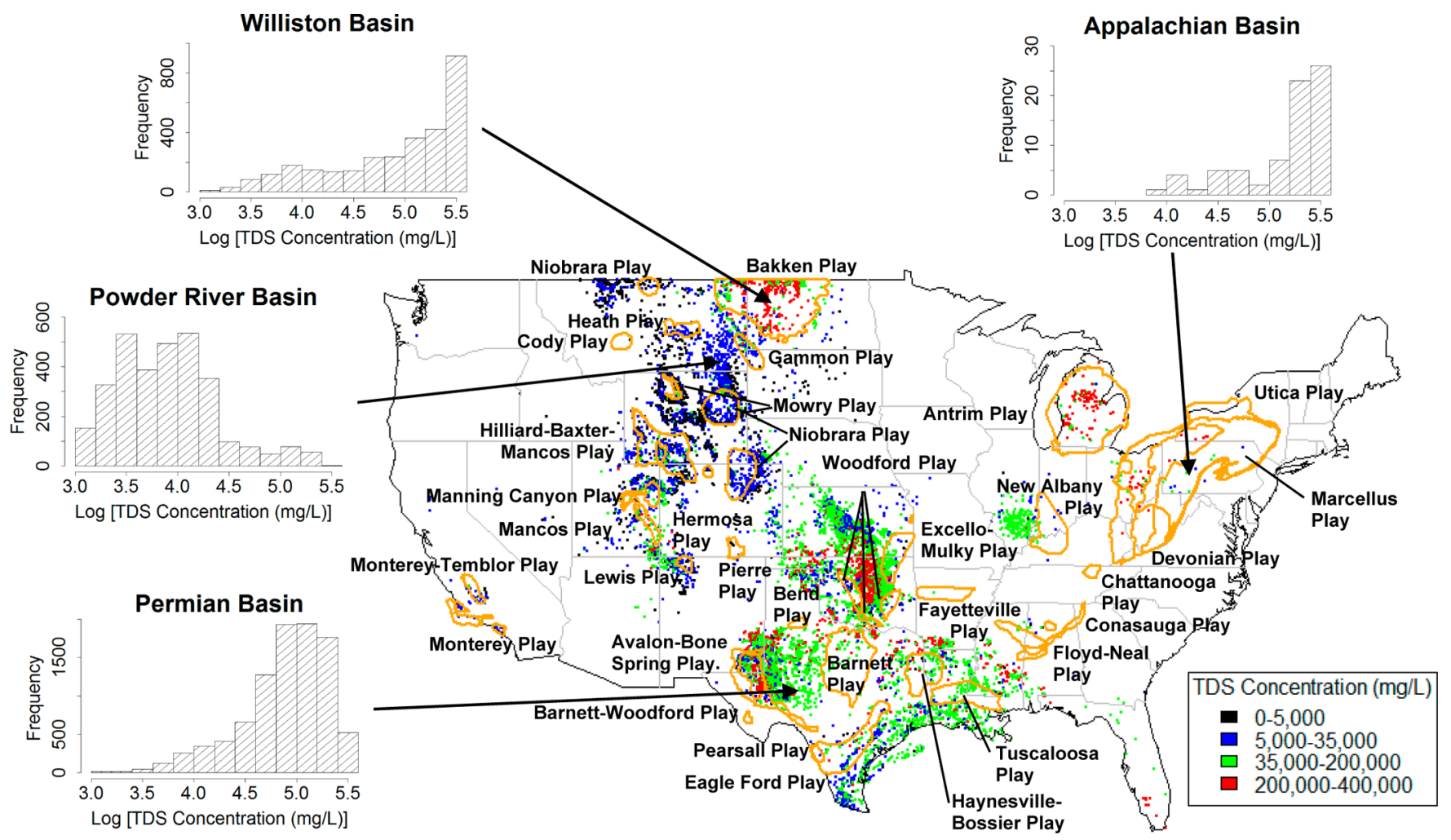

Figure 3. Map illustrating the locations of active shale plays in the contiguous United States and the ranges of produced water total dissolved solids (TDS) concentrations from the U.S. Geological Survey's Produced Waters Database ${ }^{25}$ supplemented with recent produced water quality data from the Marcellus shale play. ${ }^{33}$ Histograms illustrate the range of produced water TDS concentrations for the Williston Basin (Bakken and Gammon Shale Plays), Powder River Basin (Mowry Shale Play), Permian Basin (Avalon-Bone Spring and Barnett-Woodford Shale Plays), and Appalachian Basin (Devonian, Marcellus, and Utica Shale Plays).

concentration resulted in guidance from the Pennsylvania Department of Environmental Protection advising municipal wastewater treatment facilities discharging to the river to limit produced water volumes to $1 \%$ of the facility daily influent volume. The department also encouraged concerned consumers for whom the Monongahela is a source of drinking water to use bottled water for cooking and drinking. ${ }^{27}$

Several high-profile incidents of groundwater and surface water contamination by natural gas and hydraulic fracturing fluids also occurred in Pennsylvania in 2009-2010. These incidents occurred during well construction or as a result of poorly constructed wells, ${ }^{24}$ and they heightened public awareness of the potential negative impacts of shale gas production. As a result, the state implemented changes in regulatory requirements for shale gas well construction and wastewater storage, treatment, and disposal. ${ }^{24}$ The most significant regulatory changes were the requirement that produced water be treated at a centralized treatment facility before discharge to surface water or to a municipal treatment facility and the establishment of a monthly average TDS concentration limit of $500 \mathrm{mg} / \mathrm{L}$ in the discharge. ${ }^{28}$

The treatment requirements and TDS limit for produced water discharge to surface water in Pennsylvania increased demand for underground injection disposal and prompted greater internal reuse of produced water. ${ }^{14}$ The Marcellus shale region generally does not have favorable geology for underground injection wells, ${ }^{24}$ and only eight injection wells exist in Pennsylvania for underground disposal of produced water. ${ }^{29}$ For comparison, there are approximately 12000 such wells operating in Texas. ${ }^{29}$ For Marcellus shale operations in
Pennsylvania, underground injection of produced water primarily occurs in Ohio. Concerns that underground injection is inducing seismic events in Ohio ${ }^{30}$ may further constrain this produced water management option.

In the Marcellus shale region, shale gas producers are currently managing most produced water through internal reuse without desalination to remove dissolved solids. However, this reuse strategy is only a temporary solution. As shale gas production in the Marcellus shale play matures, opportunities to reuse produced water in developing new wells will decline while produced water pumping from established wells will continue. ${ }^{13,14}$ Whenever produced water volumes exceed demand for internal reuse, producers in the region will be driven toward external reuse opportunities, which require desalination of produced water.

The Marcellus shale region is currently the testing ground for developing and implementing technologies for produced water reuse, and thus, we review desalination technologies suitable for the produced water quality and economic, regulatory, and infrastructure considerations of this and similar shale gas regions. The reviewed technologies have potential application in shale plays worldwide where limited produced water disposal options will drive desalination of produced water whenever produced volumes exceed demand for internal reuse. Suitable technologies must be capable of desalinating high-salinity feed waters, have a low propensity for fouling, and be modular and scalable for on-site treatment at shale gas well sites. Ideally, produced water desalination technologies will use inexpensive, locally available alternative energy sources to reduce the energy costs of produced water treatment. 


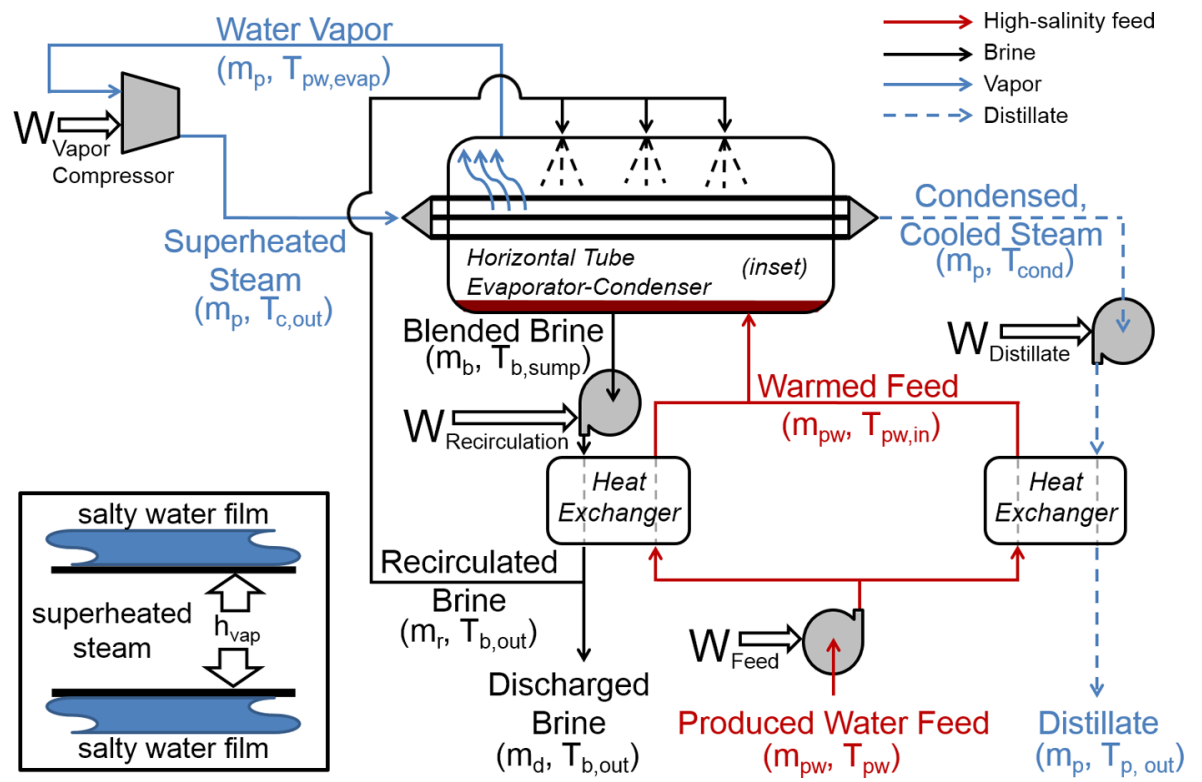

Figure 4. Schematic diagram of the mechanical vapor compression (MVC) process. After preheating, the feed stream $\left(m_{\mathrm{pw}}\right)$ is directed to the evaporator, where it is mixed with the brine accumulating in the evaporator sump. A fraction of the brine stream is bled from the system $\left(m_{\mathrm{d}}\right)$ while the remainder $\left(m_{\mathrm{r}}\right)$ is recirculated to the top of the evaporator unit to be sprayed over the outer surface of heat exchange tubes, over which water evaporates. A vapor compressor suctions the saturated vapor $\left(m_{\mathrm{p}}\right.$ at $\left.T_{\mathrm{pw} \text {,evap }}\right)$, discharging it as superheated steam into the heat transfer bundle (at $T_{c, \text { out }}>T_{\mathrm{pw}, \text { evap }}$ ). As the superheated steam flows inside the heat exchange tubes, it condenses (yielding distillate or product stream, $m_{\mathrm{p}}$ at $T_{\text {cond }}$ ) and exchanges heat with brine trickling down the tubes' outer surface (see inset). The principal energy input into the system is in the form of electrical energy required to drive the vapor compressor $\left(W_{\text {Vapor Compressor }}\right)$, and the feed, distillate, and recirculation pumps $\left(W_{\text {Feed }} W_{\text {Distillate, }}\right.$ and $W_{\text {Recirculation }}$ respectively).

\section{UNIQUE CHALLENGES OF SHALE GAS PRODUCED WATER TREATMENT}

Produced water is challenging to treat because of its complex physicochemical composition, which may vary over the lifetime of the shale gas well. Treatment technologies should be designed for these potential changes in produced water quality over time. Constituents of concern in produced water ${ }^{31}$ include dissolved and suspended organics, measured as total oil and grease; suspended solids, such as formation solids, corrosion and scale products, and bacteria; production chemicals, which may contain proppants, friction reducers, biocides, and corrosion inhibitors from the hydraulic fracturing fluid; ${ }^{12}$ naturally occurring radioactive material, specifically barium and radium isotopes; and total dissolved solids (TDS), including hardness and heavy metals.

Reducing the TDS concentration is the primary consideration for treating produced water to a quality suitable for discharge or for external reuse. Significant pretreatment to reduce fouling and scaling potential is required before produced water may be desalinated using membrane or thermal technologies. In practice, multiple technologies that target removal of different constituents are often combined in commercial produced water treatment systems. ${ }^{31,32}$

Produced water TDS concentrations vary widely according to the geographic location and geologic basin from which the produced water originates. Despite the relatively recent development of shale gas production, the hydrocarbonproducing basins in which shale plays are located are wellstudied from conventional oil and gas operations. Geochemical evaluation of produced water from Marcellus shale gas wells reveals a common process of origin and similar characteristics for the shale gas produced water and produced water from conventional oil and gas wells in the Marcellus shale region. ${ }^{33}$
Studies have concluded that the inorganic characteristics of produced water from natural gas production and from gas recovery from underground storage are controlled primarily by the geology of the surrounding rock formation. ${ }^{34,35}$ Consequently, the U.S. Geological Survey's Produced Waters Database $^{25}$ for oil and gas production wells in established hydrocarbon-producing basins may be used to describe the general quality of produced water from major shale gas plays in the United States. Figure 3 shows the locations of major shale gas plays in the contiguous United States and the ranges of produced water TDS concentrations for individual wells and selected hydrocarbon-producing basins from the database. Produced water TDS concentrations reported in the database range from 1000 to $400000 \mathrm{mg} / \mathrm{L}$.

The TDS concentration of produced water constrains the selection of appropriate desalination technologies. Reverse osmosis is typically employed to treat saline water, such as seawater, with TDS concentrations of up to approximately $35000 \mathrm{mg} / \mathrm{L},{ }^{36,37}$ which results in a feed solution TDS concentration of approximately $70000 \mathrm{mg} / \mathrm{L}$ for desalination at $50 \%$ recovery. The hydraulic pressure required to overcome the osmotic pressure of high-salinity solutions can exceed the allowable pressure of the reverse osmosis membrane modules and other process equipment. ${ }^{36,37}$ Consequently, high-salinity waters with TDS concentrations greater than approximately $35000 \mathrm{mg} / \mathrm{L}$, representing a TDS concentration of $70000 \mathrm{mg} /$ $\mathrm{L}$ at $50 \%$ recovery, must be desalinated by more energy intensive thermal technologies. ${ }^{36,37}$ Conventional thermal desalination technologies, such as multistage flash and multiple effect distillation, are well established. However, the high investment $\operatorname{costs}^{38}$ and the significant energy requirements and associated energy costs of these technologies ${ }^{36}$ limit their implementation. The comparatively larger footprint and more costly materials and equipment of conventional thermal 
desalination technologies compared to membrane desalination technologies $^{38}$ also imply that they are less mobile and scalable.

\section{TECHNOLOGIES FOR PRODUCED WATER DESALINATION AND REUSE}

Mechanical vapor compression, membrane distillation, and forward osmosis are three desalination technologies for highsalinity brines that are appropriate for the produced water in the Marcellus shale region as well as other shale gas plays worldwide where conditions promote external reuse. As described herein, these technologies can achieve stringent permeate TDS concentration limits for external reuse opportunities, their modular nature is conducive to the infrastructure constraints of on-site treatment at shale gas well sites, and their energy requirements and associated costs are competitive compared to more conventional thermal technologies. Mechanical vapor compression is a relatively well-established technology, while membrane distillation and forward osmosis are emerging technologies that show promise for low-energy desalination of high-salinity water. We present a process overview of the three technologies and discuss the advantages and disadvantages of each for produced water desalination.

Mechanical Vapor Compression. Mechanical vapor compression (MVC) is a separation process that uses electrical energy to supply thermal energy for desalination. MVC is being used in seawater desalination as well as the desalination of produced water from heavy oil fields that employ steam-assisted gravity drainage for oil recovery. ${ }^{39-41}$ MVC consists of an open-loop heat pump, where a compressor, driven by an electrical motor, supplies the energy required to evaporate water from a high-salinity feed. ${ }^{39}$ A flow diagram of the MVC process is shown in Figure 4.

In an MVC system, the feed stream to be desalinated is preheated by two plate heat exchangers using the heat provided by the distillate and brine streams leaving the system. The feed is then pumped to an evaporator-condenser, where it is mixed with the brine accumulating at the sump of the evaporator. Some of this slurry is bled from the system to remove accumulated dissolved solids. A recirculation pump conveys the remainder of the slurry to a nozzle distribution system, which evenly spreads the slurry over a bundle of heat transfer tubes to form a continuous falling film. Evaporating water is suctioned by the vapor compressor, which discharges superheated steam to the heat transfer tubes. As it passes through the heat transfer tubes in the evaporator-condenser, the superheated steam condenses, providing the enthalpy of vaporization for the slurry trickling down the outer surfaces of the tube bundle. ${ }^{40}$ The falling film pattern results in high heat transfer rates, thereby minimizing the compression ratio and the work to drive the compressor. ${ }^{42}$ Both condensate and brine streams are pumped out of the evaporator-condenser before being discharged or recycled. Noncondensable gases are removed from the evaporator through a secondary condenser and exhausted through a rotary vacuum pump. ${ }^{39,40}$ Typical operating conditions for MVC seawater desalination units are an evaporator operating temperature of $60{ }^{\circ} \mathrm{C}$ and a compression ratio of 1.1. . $^{40}$

An alternate MVC system configuration, which has been adopted to optimize the heat transfer coefficient, uses evaporators with a vertical tube bundle. In this configuration, the feed stream forms a falling film inside the heat exchanger tubes where the water vaporizes. The heat of vaporization is provided by superheated steam from the compressor, which flows over the external surface of the heat transfer tubes and condenses as distilled water. ${ }^{43}$

Both the heavy oil production and seawater desalination industries have adopted MVC technology, with more than 200 MVC units commissioned worldwide. ${ }^{41}$ In heavy oil fields employing steam assisted gravity drainage, MVC is regarded as the standard method for produced water desalination and subsequent reuse for steam generation using drum boilers. ${ }^{43}$ MVC has been used to treat produced water from German and Dutch heavy oil fields. ${ }^{39}$ After separation of the extracted hot oil and produced water, MVC is used to desalinate the produced water fraction, generating distillate and brine streams. The distillate is used as the feed for boiler water in the steam recovery process, thus eliminating the need for reinjection of the produced water to the depleted oil reservoir. ${ }^{39}$ Numerous heavy oil fields have implemented MVC for the treatment and reuse of produced water, replacing traditional methods including warm lime softening, filtration, and weak acid cation ion exchange. ${ }^{43}$

The process performance of MVC units varies slightly depending on the application. An MVC unit deployed in heavy oil fields to desalinate high-salinity produced water (TDS concentration of $64000 \mathrm{mg} / \mathrm{L}$ ) for use as boiler feed water exhibited a distillate capacity of $600 \mathrm{~m}^{3} /$ day $(4000 \mathrm{bbl} /$ day $)$ at $30 \%$ recovery (mass of distillate per mass of feed). ${ }^{39}$ The specific energy consumption was $13.6 \mathrm{~kW} \mathrm{~h} / \mathrm{m}^{3}$ distillate. MVC seawater desalination units treating seawater streams (TDS concentration of approximately $38000 \mathrm{mg} / \mathrm{L}$ ) are capable of producing $500 \mathrm{~m}^{3} /$ day $(3000 \mathrm{bbl} /$ day $)$ of distilled water at an energy consumption of $10.4-11.2 \mathrm{~kW} \mathrm{~h} / \mathrm{m}^{3}$ distillate when operating at $40 \%$ recovery. ${ }^{40}$ Process performance (i.e., mass of distillate per unit energy input) increases with capacity, ${ }^{46}$ and given the weak dependence of vapor pressure on $\mathrm{NaCl}$ concentration, ${ }^{44}$ process performance appears to decrease only slightly with feed salinity ${ }^{45}$ at brine concentrations similar to seawater. ${ }^{46}$

Use of MVC for TDS removal presents a number of advantages compared to other technologies. In heavy oil recovery, produced water desalination by MVC has reduced treatment complexity and waste stream emissions compared to traditional treatment processes involving deoiling, softening, filtration, and ion exchange. ${ }^{43}$ In addition, capital costs are lower due to the modularized design of the evaporator, and operating costs are reduced compared to traditional processes. ${ }^{43}$ The modular nature of the technology also implies that capacity can be increased by addition of evaporatorcondenser units. ${ }^{40}$ Recycling desalinated water as boiler feed for heavy oil recovery also eliminates the need for disposing of the produced water, which can be produced at four times the volume of oil recovered. ${ }^{39}$

Compared to membrane-based seawater desalination technologies, MVC is advantageous in that it is less prone to fouling by oil and grease, and therefore, less extensive pretreatment may be necessary prior to MVC desalination. ${ }^{40,43}$ Feed pretreatment by deoiling and antiscalant dosing (to prevent corrosion of and precipitation on the heat exchangers) is typical of MVC units. ${ }^{40,43}$ The solubility of $\mathrm{NaCl}$ in water (approximately $370000 \mathrm{mg} / \mathrm{L}$ at $60{ }^{\circ} \mathrm{C}$ ) ${ }^{47}$ imposes an upper TDS concentration limit near $200000 \mathrm{mg} / \mathrm{L}$ for MVC feed water. ${ }^{48}$ Finally, when volatile organic compounds are present in the product stream, secondary treatment (e.g., pervaporation $)^{49}$ will be required. 
The primary disadvantage of MVC compared to other produced water desalination technologies is its relatively high energy requirement of $10.4-13.6 \mathrm{~kW} \mathrm{~h} / \mathrm{m}^{3}$ distillate, due primarily to the electric power required to drive the vapor compressor. ${ }^{39,40}$ Unlike other desalination technologies, such as membrane distillation or forward osmosis, MVC requires highgrade electrical energy to perform the separation. This, in turn, necessitates access to an existing power grid or other continuous supply of electricity. ${ }^{50,51}$ Improvements in the heat transfer coefficient (e.g., through dropwise condensation) could decrease the energy requirements and associated operating costs. $^{52}$

Membrane Distillation. Membrane distillation (MD) is an emerging technology that can utilize low-grade heat to drive separation. In $\mathrm{MD}$, the aqueous feed stream is separated from the permeate by a hydrophobic, microporous membrane. Liquid is unable to penetrate the membrane pores due to the hydrophobic nature of the membrane, and a difference in the partial vapor pressure drives the transport of water vapor across the membrane pores (Figure 5A). ${ }^{53-58}$ Previous studies have focused on four main configurations: direct contact, air gap, sweeping gas, and vacuum MD. These configurations differ primarily in the way the vapor pressure gradient is maintained and the condensation method for the vapor permeate. ${ }^{53-55,57,58}$ In addition to being the simplest configuration, direct contact MD has been studied most extensively and is identified as the most suitable configuration for purification of feed streams with nonvolatile solutes, such as desalination applications. ${ }^{57}$ Hence, for straightforwardness, we discuss only direct contact $\mathrm{MD}$, but the identical principles allow other MD configurations to be similarly applied for produced water desalination.

In direct contact $\mathrm{MD}$, the temperature difference between a warm feed solution and an ambient temperature aqueous permeate stream drives water vapor flux. ${ }^{53-55,57,58}$ Ions, colloids, and macromolecules are nonvolatile, and hence, they are retained in the feed, yielding pure water as the permeate product. ${ }^{55,57-59}$ Because the logarithm of the vapor pressure is linearly proportional to the reciprocal temperature (ClausiusClapeyron relation), conducting $\mathrm{MD}$ at a higher feed solution temperature will result in a larger driving force and will generate exponentially greater vapor fluxes (Figure 5D, solid blue line), improving productivity. ${ }^{53,55,57,60}$ Additionally, the process efficiency is enhanced at higher feed temperatures, as illustrated by the dashed green line in Figure 5D, which represents the fraction of thermal energy that is utilized for vaporizing water (i.e., permeate production) instead of being dissipated by conductive heat loss across the membrane. ${ }^{60,61}$

Water flux rates in MD are only slightly sensitive to the feed salinity. ${ }^{57,58,62}$ For example, a study found that increasing the TDS concentration of the feed from 35000 to $75000 \mathrm{mg} / \mathrm{L}$ reduces the resultant permeate flux by only $5 \% .{ }^{60}$ This feature makes MD particularly suited to desalinate high-salinity sources, such as produced waters, without incurring substantial productivity penalties. Almost complete salt rejection has consistently been reported in the literature, even for very high salinity feeds. ${ }^{63-65}$ Compared to pressure-driven membrane processes, such as reverse osmosis, $\mathrm{MD}$ has a lower fouling propensity due to larger membrane pores and the absence of an applied hydraulic pressure. ${ }^{53,55,57,58}$ The relatively small physical footprint and modular nature of MD affords further versatility in adapting the technology to the unique infrastructure challenges of shale gas well sites. ${ }^{57}$
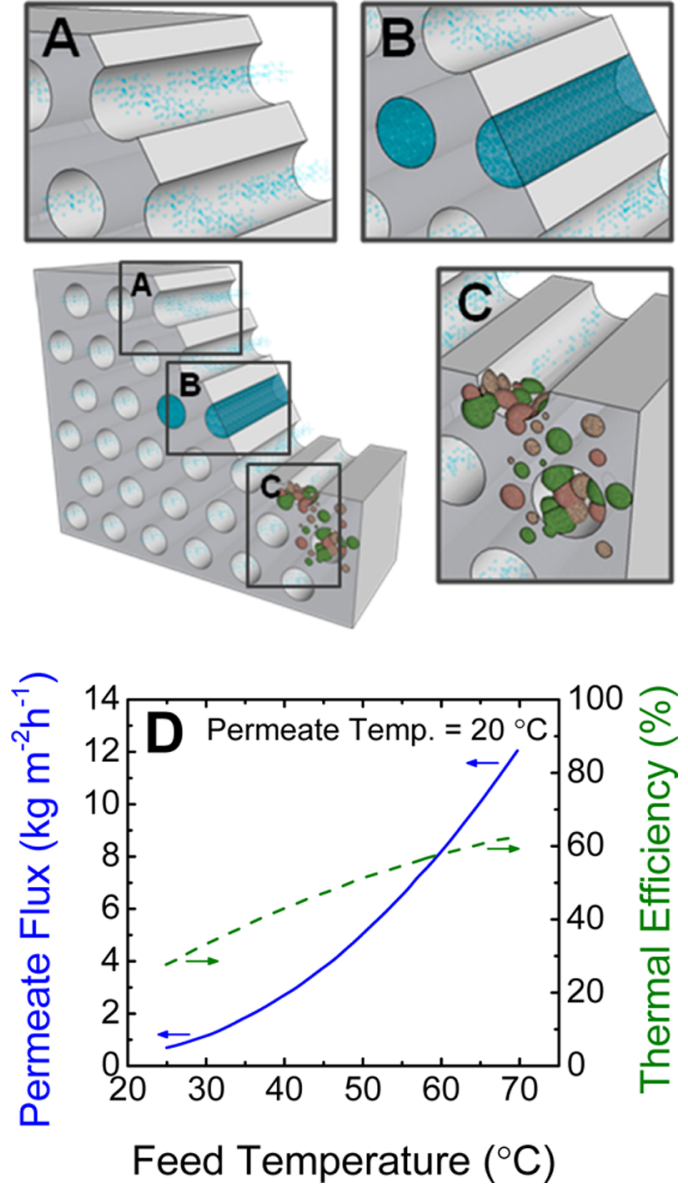

Figure 5. Conceptual illustration of membrane distillation (MD). (A) The temperature difference between the warmer feed and cooler permeate streams gives rise to a vapor pressure gradient which drives the transport of water vapor across the membrane pores. (B) Wetting of the pores, where the aqueous solution penetrates the hydrophobic membrane, results in the feed solution flowing directly across the membrane, causing permeate quality to deteriorate. (C) Fouling of the MD membrane leads to performance decline, such as flux decay. (D) Permeate flux (blue solid line, left vertical axis) and thermal efficiency (green dashed line, right vertical axis) as a function of the feed temperature for a typical commercial polypropylene membrane, with permeate temperature set at $20^{\circ} \mathrm{C} .{ }^{60}$

The composition of produced water can pose distinctive challenges to MD. Small organic compounds and dissolved gases that exert partial vapor pressures comparable to or higher than water are transported across the membrane with the water vapor flux, causing contamination of the permeate stream. ${ }^{53,55,56}$ Certain feed components, such as alcohols and surfactants, can lower the liquid surface tension of the feed solution and cause wetting of the membrane pores (Figure 5B).$^{53,56,57}$ The feed solution can then flow directly across the membrane through the wetted pores, deteriorating permeate quality. To restore the vapor-liquid interface at the pores, the wetted membrane must be taken out of operation and dried completely, resulting in process downtime. ${ }^{53}$ Although fouling is reduced in $\mathrm{MD}$ compared to conventional pressure-driven membrane processes, it can, nonetheless, have detrimental impacts on performance. Fouling clogs membrane pores, which leads to flux decline and pore wetting and imposes additional hindrance to heat and mass transfer (Figure 5C). Mineral scaling is anticipated to be an important detrimental 
phenomenon given the high salinity of the produced water feed solution and the presence of salts close to their saturation concentrations. ${ }^{55-57,66-68}$ The deleterious effects of particulate, organic, and biological fouling can also diminish process productivity. ${ }^{53,55,56,62,67,69}$

Pretreatment to remove foulants and periodic membrane cleaning will likely be necessary to maintain the productivity of desalination by MD. ${ }^{62,65,67,70-72}$ Pretreatment should also be designed to remove components from the produced water feed that induce membrane pore wetting. Using membranes with smaller pore sizes and more hydrophobic material can also help minimize such facilitated wetting. ${ }^{53-58}$ To meet product water quality standards, post-treatment might be required to remove volatile compounds and gases transported into the permeate from the feed solution. ${ }^{64}$ Pre- and post-treatment steps, as well as membrane cleaning, will be important considerations in the implementation of MD technology as they levy additional chemical and energy costs on the overall process. ${ }^{57,60}$ Due to the variability in the produced water composition, it is foreseeable that pre- and post-treatment protocols, cleaning strategies, and membrane design will have to be tailored to the specific water quality of the produced water source. ${ }^{57}$

The minimum energy required to desalinate produced water in a hypothetical MD system without energy recovery devices is equivalent to the enthalpy of vaporization of the high-salinity

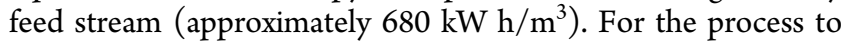
be energetically viable, energy recovery devices such as heat exchangers will be necessary to reuse the thermal energy. However, $\mathrm{MD}$ is uniquely positioned to leverage the inherently elevated temperatures of the produced water feed solutions to drive the separation, ${ }^{22,73}$ and thus, it has the potential to be a low energy input desalination technology. Produced water temperature could be as high as $100{ }^{\circ} \mathrm{C}$, as discussed subsequently in the Sources of Energy for Produced Water Desalination section of this review. Pairing produced water that is already at a temperature between 60 and $80{ }^{\circ} \mathrm{C}$ with a permeate stream at $20{ }^{\circ} \mathrm{C}$ can yield operationally practical water fluxes and thermal efficiencies (Figure 5D). Thermal energy of the warm produced water is utilized to provide the driving force for separation, and as such, the process requires only auxiliary inputs, such as electricity to circulate the solutions, and chemical and energy costs for pre- and posttreatment steps. ${ }^{57,60,61}$ In cases where the produced water is not sufficiently hot to generate practical fluxes, additional thermal energy can be supplied to elevate the feed solution temperature and enhance productivity. This supplementary energy input can be partially recovered by using heat exchangers to capture the thermal energy of the heated permeate stream leaving the MD module. ${ }^{54,74,75}$ A recent study estimates that operating $\mathrm{MD}$ with heat recovery (with feed solutions initially at ambient temperature) can potentially lower the thermal energy consumption to approximately $40 \mathrm{~kW} \mathrm{~h} / \mathrm{m}^{3}$ of product water (approximately $140 \mathrm{~kJ} / \mathrm{kg}$ ). ${ }^{60}$

The ability to utilize the inherent low-grade heat of the feed stream to produce operationally adequate water fluxes affords $\mathrm{MD}$ unique opportunities to be an attractive, low-energy technology for shale gas produced water desalination. However, MD will be challenged by the geospatial variability and the complexity of the produced water composition. The potential application of $\mathrm{MD}$ to desalinate produced water has been the topic of recent investigations, ${ }^{64,65}$ but more studies are necessary to further our understanding of the potential difficulties, develop suitable membranes, optimize operating parameters in membrane modules, and formulate effective preand post-treatment strategies in order to the advance the implementation of MD.

Forward Osmosis. Forward osmosis (FO) removes TDS in a membrane-based separation process. Similar to reverse osmosis desalination, and unlike MVC or MD, FO achieves dissolved solids removal without the liquid permeate undergoing a phase transition. Permeate water passes across a highly selective membrane that retains dissolved solutes in the feed water. The primary difference between forward and reverse osmosis is the driving force for separation. In reverse osmosis, hydraulic pressure is applied to overcome the feed water osmotic pressure. However, in FO, water flux is driven by an osmotic pressure difference between the feed solution and a concentrated draw solution on the permeate side that has a higher osmotic pressure than the feed. The flow of permeate from the feed to the draw dilutes the draw solution and reduces the osmotic pressure gradient that drives separation. Consequently, an additional draw solution regeneration step is required for separation of the draw solute from the permeate and reconcentration of the diluted draw solution. ${ }^{76}$

Forward osmosis has several advantages compared to other technologies for desalinating high-salinity feed waters. Because it is driven by osmotic pressure rather than hydraulic pressure, FO can desalinate high-salinity feed waters using simple and inexpensive low-pressure equipment. Unlike reverse osmosis, FO is not limited by the high-pressure operating limit that corresponds to a solution TDS concentration of approximately $70000 \mathrm{mg} / \mathrm{L}^{36,68,77}$

Low-pressure operation of FO also translates to a relatively low propensity for irreversible fouling of the membrane. ${ }^{78-80}$ Organic foulants that accumulate on the membrane surface tend to be less compact than similar fouling layers in a pressurized system, and the fouling layers can be more easily removed. This low fouling propensity can improve the overall FO process efficiency by reducing the pretreatment requirements for produced water and their associated energy and costs. In addition, low fouling propensity is expected to require less aggressive and frequent membrane chemical cleanings, leading to longer membrane life and reduced replacement costs. Another specific advantage of FO for shale gas produced water desalination is the modularity of the treatment system, which allows the capacity to be scaled up with the addition of membrane modules.

The selection of an appropriate draw solute is crucial for FO process efficiency. The draw solution must generate high osmotic pressure and be separated and reconcentrated efficiently with low energy costs. These restrictions are more pronounced when using FO to desalinate shale gas produced water because the high-salinity produced water requires a draw solution with a very high osmotic driving force, and the remote and temporary nature of shale gas well sites may limit the available energy sources for draw solution regeneration. Draw solutes that cannot generate a sufficiently high osmotic pressure, such as magnetic nanoparticles, ${ }^{81}$ stimuli-responsive polymer hydrogels, ${ }^{82}$ and polyelectrolytes ${ }^{83}$ are not suitable for FO desalination of high-salinity produced water.

Dissolved salts are the preferred draw solute as they can generate high osmotic pressures and be rejected by the membrane. In a closed-loop system, the draw solution of dissolved salts must be regenerated. Because the draw solution must have higher osmotic pressure than the feed, reverse osmosis cannot be used to reconcentrate the draw solution 

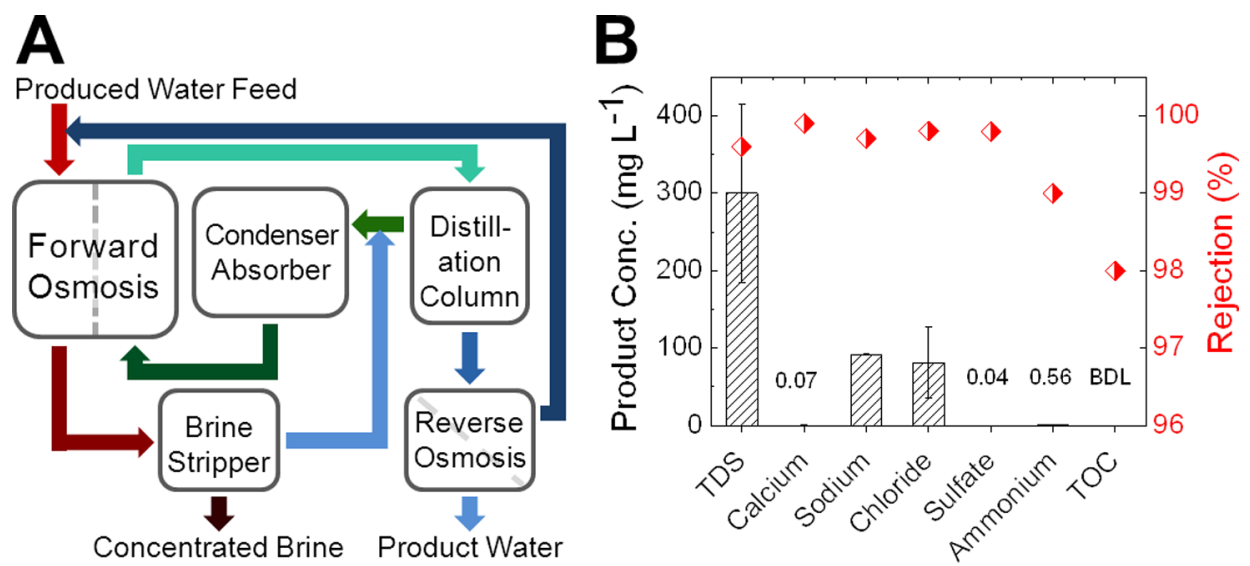

Figure 6. (A) Schematic illustration of a forward osmosis (FO) pilot system for produced water desalination (adapted from ref 92). (B) Product water concentrations (bars, left vertical axis) and corresponding percent rejection (symbols, right vertical axis) of total dissolved solids (TDS), total organic carbon (TOC), and representative major cations and anions in the for an FO pilot-scale system desalinating produced water (data from ref 92). The "BDL" next to TOC means "below detection limit".

when the feed salinity is higher than the corresponding technical pressure limitation of reverse osmosis. Consequently, previously suggested draw solutes that rely on reverse osmosis for regeneration, such as $\mathrm{MgSO}_{4}{ }^{84}$ and $\mathrm{NaCl}^{68,85}$ are not applicable for produced water treatment.

A draw solution of dissolved salts may also be treated as a sacrificial draw solution, ${ }^{86}$ meaning that the diluted draw solution will be used as-is rather than being regenerated and returned to the membrane. In this configuration, water is transferred from the feed to the draw so that FO will essentially serve as a pretreatment for the feed stream. The sacrificial draw approach is the basis for the Green Machine by Hydration Technology Innovations. ${ }^{87}$ The Green Machine uses a concentrated $\mathrm{NaCl}$ draw solution to treat produced water. Following treatment, the diluted $\mathrm{NaCl}$ draw solution, which remains at a TDS concentration greater than or equal to the produced water feed, is recycled for well development activities. $^{87}$

Thermolytic salts, which can change phase via a change in solution temperature, are the most suitable FO draw solute candidates for desalinating high-salinity produced water. Thermal energy can be used in draw solution regeneration to volatilize the thermolytic solutes, recover the permeate water, and reconcentrate the draw solution. A thermal draw solution recovery process does not have the restriction of a maximum operating hydraulic pressure. Therefore, it can achieve separation of the draw solute from the permeate water even in highly concentrated draw solutions. When an inexpensive, low-grade heat source is available to fuel the thermal separation, it may be possible to significantly reduce the thermal energy costs, ${ }^{88}$ such as using a geothermal source for produced water desalination.

Currently, ammonia-carbon dioxide is the most mature thermolytic draw solute in terms of research and development. ${ }^{7789-91}$ An ammonia-carbon dioxide draw solution contains ammonium salts that can generate osmotic pressures greater than $200 \mathrm{~atm}^{89}$ and be decomposed to ammonia and carbon dioxide gases at a relatively low temperature (approximately $60{ }^{\circ} \mathrm{C}$ at atmospheric pressure). ${ }^{77}$ In an FO system, the ammonia and carbon dioxide gases are captured and condensed to reconcentrate the draw solution. Seawater desalination by ammonia-carbon dioxide FO has been widely discussed because of the high osmotic pressure of the draw solution, the facile draw regeneration procedure, and the potential to use low-cost thermal energy for draw solute recovery. ${ }^{90,91}$ The ability of the ammonia-carbon dioxide draw solution to generate significant water fluxes when desalinating a high-salinity feed solution (TDS concentration of $140000 \mathrm{mg} /$ L) was demonstrated in early research. ${ }^{89}$

Recently, a pilot-scale operation of an FO system using ammonia-carbon dioxide draw solution demonstrated the potential for desalinating shale gas produced water (Figure $6 \mathrm{~A}) .{ }^{92}$ The feed was a shale gas produced water from the Marcellus shale region with an average TDS concentration of $73000 \mathrm{mg} / \mathrm{L}$. Due to the high-salinity feed and the targeted high water recovery, a reverse osmosis step was used as a second desalination pass for the permeate after FO in order to achieve a permeate TDS concentration lower than $500 \mathrm{mg} / \mathrm{L}$. However, this secondary RO step may not be necessary when considering less strict salinity standards for produced water discharge. A distillation column and condenser were used to regenerate the draw solution. The pilot successfully achieved $64 \%$ water recovery, desalinating produced water to achieve a permeate TDS concentration less than $300 \mathrm{mg} / \mathrm{L}$. In addition, the permeate had a very low concentration of total organic carbon (TOC), and the concentrations of major cations and anions reached potable water values (Figure 6B). The resulting concentrated feed water had an average TDS concentration of $180000 \mathrm{mg} / \mathrm{L}$. Although reported water fluxes from the pilot study were relatively low (approximately $3 \mathrm{~L} /\left(\mathrm{m}^{2} \mathrm{~h}\right)$ ), further optimization and development in both membrane de$\operatorname{sign}^{76,86,93,94}$ and in module hydrodynamics ${ }^{95}$ are expected to improve the flux.

An energy analysis of the pilot ammonia-carbon dioxide FO system showed that $97 \%$ of the consumed energy was thermal, and the remainder was electrical. The specific energy consumption of the FO pilot system was shown to be significantly lower (2.3 times less) than other thermal distillation methods. This is due primarily to the fact that, in traditional thermal distillation methods, the feed water is evaporated at a latent heat of evaporation of $2260 \mathrm{~kJ} / \mathrm{kg}$, while in forward osmosis, smaller volumes of ammonia and carbon dioxide are evaporated at latent heats of vaporization of 1369 and $574 \mathrm{~kJ} / \mathrm{kg}$, respectively. ${ }^{96}$ A suggested opportunity for additional significant energy savings is recovering the energy released during condensation of the ammonia and carbon 
dioxide gases, in a similar manner to the recovery of the water vapor latent heat in MVC. ${ }^{92}$ In an analysis including energy recovery, the ammonia-carbon dioxide FO system had a specific energy consumption $42 \%$ less than a single-stage MVC system operating under the same conditions $(21$ and $37 \mathrm{~kW} \mathrm{~h} /$ $\mathrm{m}^{3}$ of permeate, respectively). ${ }^{92}$ Another potential opportunity for energy savings is using the heat of elevated-temperature produced water to help recover ammonia and carbon dioxide gases to regenerate the draw solution.

Despite the potential of the ammonia-carbon dioxide draw solution, it suffers from ammonia loss due to reverse solute flux through the FO membrane from the draw to the feed side. One way to resolve the ammonia reverse flux is stripping the ammonia from the feed stream after FO treatment in order to recycle it and to minimize the draw solute loss (Figure 6A). In the discussed pilot-scale system, the reported ammonia concentration in the product water after stripping was less than $1 \mathrm{mg} / \mathrm{L} .{ }^{92}$ Other ways to improve the reverse draw solute flux involve the development of membranes that are more selective against ammonia or identifying other effective thermolytic draw solutes.

Trimethylamine (TMA) may be a promising thermolytic draw solute alternative to ammonia. ${ }^{97}$ Its thermodynamic properties suggest comparable volatility to ammonia, and the reverse draw solute flux of TMA would be reduced compared to ammonia because the larger TMA molecule is better rejected by the FO membrane. Switchable polarity solvents (SPSs) ${ }^{98,99}$ may be another alternative to ammonia-carbon dioxide. SPSs are a class of relatively large amine solvents that change their polarity and, thus, their miscibility in water, upon $\mathrm{pH}$ change initiated by the introduction or removal of carbon dioxide in solution.

While TMA and SPSs show potential as draw solutes for FO, they are still at early stages of investigation. However, a pilotscale FO system using an ammonia-carbon dioxide draw solution has demonstrated the ability to treat high-salinity shale gas produced water using less energy than conventional thermal methods. The relatively low specific energy consumption of FO, combined with advantages such as low propensity for irreversible fouling, modularity, and the potential to use lowgrade heat as the energy source, indicate that FO can be a potential desalination technology for external reuse of highsalinity shale gas produced water.

\section{SOURCES OF ENERGY FOR PRODUCED WATER DESALINATION}

The reviewed technologies for desalination of produced water involve significant consumption of energy. As thermally driven separation processes, their efficiency is inherently low. ${ }^{100}$ This low energy efficiency is unavoidable in produced water desalination because nonthermal processes with higher efficiencies cannot desalinate such high-salinity feed waters. The potential location of these treatment processes at well sites, often away from substantial infrastructure, suggests that supplying energy may be a critical challenge to the widespread desalination of produced water for external reuse. We therefore examine considerations and options for feasibly powering these technologies with available resources according to their thermal and electrical energy needs. As some debate currently surrounds the claim that natural gas represents a lower-carbon energy source, ${ }^{101,102}$ we give special attention to the environmental implications of using each potential energy resource.
The modular construction, scalability, and lack of emissions associated with solar energy make it immediately appealing for generation of electrical or thermal energy, either directly or from solar electrical energy. The ability to transport solar energy capturing equipment between well sites as produced water flow rates fluctuate is another distinct advantage. However, solar power cannot be the primary energy source for produced water desalination for several reasons. First, the intermittency of solar exposure would necessitate the use of an alternative energy source to maintain a constant power supply for continuous operation. The footprint of a supply system, particularly for thermal energy, could also be prohibitively large when some concerns about disruption of current land use already exist. ${ }^{103,104}$ In addition, the Marcellus shale region experiences relatively low levels of solar radiation, and the resulting payback period without incentives is decades long for both photovoltaics and solar water heating systems. ${ }^{105}$ However, this payback period would shrink considerably when solar energy capture is compared with the default alternative for off-grid power production: diesel-powered generators. Solar energy becomes competitive in the Marcellus region against effective costs of $\$ 0.2-\$ 0.3$ per $\mathrm{kW}$ h or $\$ 3.5-\$ 4$ per therm. ${ }^{105}$ At present, solar energy appears to be useful only as a supplemental source of electricity at Marcellus well sites. It would be better suited for other shale plays that receive more solar radiation or under scenarios with enhanced economic incentive.

Geothermal energy, however, would be readily and continually available at well sites in the Marcellus shale region. The elevated temperatures of extracted gas and produced water in this play and many others are a source of significant energy (Figure 7A). In the western United States, temperatures may exceed $100{ }^{\circ} \mathrm{C},{ }^{106}$ facilitating electricity generation at the well site. ${ }^{107}$ The lower temperatures that prevail in the eastern U.S. are more suitable for direct thermal uses of energy. This energy could be easily exploited to power MD or FO desalination of produced water, at least in part. While this energy source cannot be shifted between well sites to address spatiotemporal variability in demand for produced water desalination energy, as solar energy production could be, the relative simplicity of its capture gives it a significant advantage. If additional heat is required, a geothermal well could be constructed at the well site using essentially the same expertise and equipment used to drill the gas-producing wells. Drilling deeper will also yield higher temperatures, though at increased initial cost.

Although temperature data at typical hydraulic fracturing depths are not currently available across the Marcellus shale, estimates can be made. Figure 7 maps temperatures $3.5 \mathrm{~km}(2.2$ mi.) below the ground surface (bgs), based on measured field data and some modeling. ${ }^{106}$ Marcellus shale gas wells will not reach this depth or temperature; their maximum depth will be approximately $2.7 \mathrm{~km}(1.7 \mathrm{mi}) .^{24}$ The general rule based on shallower water well development, an increase of $1{ }^{\circ} \mathrm{F}\left(0.6{ }^{\circ} \mathrm{C}\right)$ per $100 \mathrm{ft}$ of depth, ${ }^{108}$ likely underestimates the temperature of produced water within the Marcellus shale. In southwestern or northeastern Pennsylvania, this guideline would estimate $57^{\circ} \mathrm{C}$ temperatures for the deepest shale gas wells. However, the rule would give $72{ }^{\circ} \mathrm{C}$ at $3.5 \mathrm{~km}$ bgs, a significant underestimation of the more data-based temperature range of $100-125{ }^{\circ} \mathrm{C}$ indicated for those regions in Figure 7. Therefore, the true maximum temperature in the Marcellus, at its deepest wells, is likely $60-100{ }^{\circ} \mathrm{C}$. Thermal energy at this temperature would be highly useful for the desalination technologies reviewed herein. 


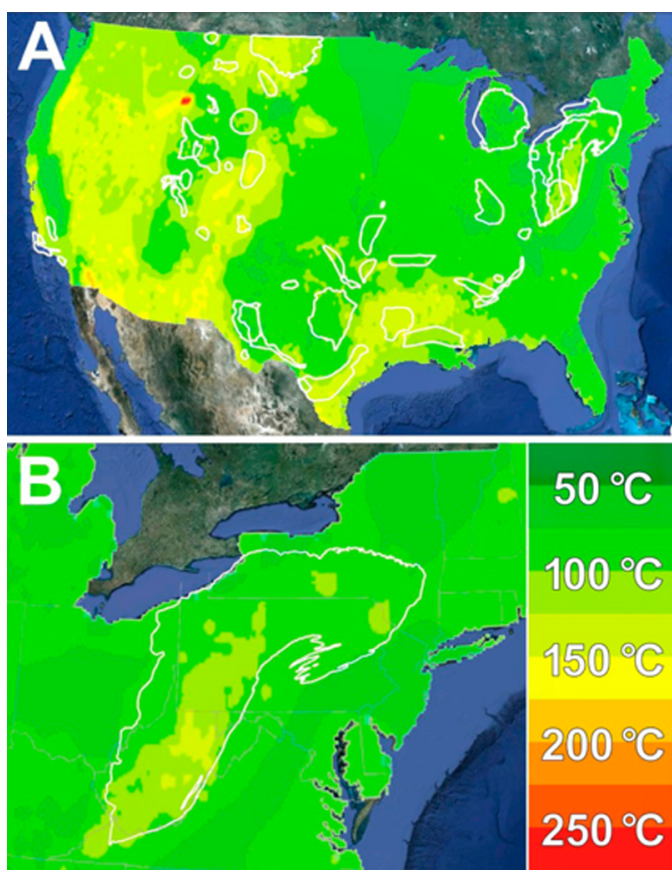

Figure 7. Temperature $3.5 \mathrm{~km}$ (2.2 miles) below the ground surface (data from ref. 106) in (A) the contiguous U.S., with major shale plays outlined (data from ref. 109), and (B) the northeastern U.S., with the Marcellus shale play outlined. The Marcellus shale is found at depths of up to about $2.7 \mathrm{~km} .{ }^{24}$ Data displayed in Google Earth (Data SIO, NOAA, U.S. Navy, NGA, GEBCO; Image USGS Copyright 2013 CnesSpot Image; Image Copyright 2013 TerraMetrics; Copyright 2013 Google).

Further development of geothermal resources could also take place in a location central to several wells to balance the cost of transport to a central, but still nearby, treatment facility with the benefit of aggregating produced water flow rates and quality to dampen fluctuations in the feed stream. By siting geothermalenergy wells closer to existing commercial or residential buildings, a long-term benefit of this development could be realized for the local population. After the cessation of natural gas exploration and production in the area, the geothermal energy resource could remain available to the community for sustainable and low-cost temperature control for buildings. Thus, the oil and gas industry would be helping to provide clean sources of energy for the future while also working to supply adequate energy for today's population in the context of today's infrastructure.

While clean, renewable energies can significantly contribute to the energy requirements of produced water treatment, some situations will inevitably require more conventional on-demand energy. Under certain economic and regulatory drivers, it may be advantageous to utilize a portion of the just-produced natural gas at the well site as an energy supply rather than diesel fuel. This would reduce direct emissions, eliminate the transportation of fuel to the well site, and conserve the costs of processing the natural gas for long-distance distribution, including the potential loss of natural gas through leaks in pipelines. Processing of natural gas typically includes some processing at the well site and additional processing at a centralized facility. Water, acid, unsuitable gases, and condensates are removed to enhance the product heating value and to protect the distribution system. In shale plays where the gas has little acid, as anecdotal evidence suggests may be the case in the Marcellus, it may be feasible to burn justproduced, minimally processed natural gas to boost thermal energy on an as-needed basis. This possibility highlights again the importance of regulatory and economic drivers in determining the fate of produced water; the gas industry will not consume their primary product in desalinating water for reuse without significant incentive.

The current state of technology and research does not support exhaustive and direct comparisons between these technologies in terms of their energy use profile. Nevertheless, some comparisons can be made and are included in Table 1. As these technologies mature, particularly for $\mathrm{FO}$ and $\mathrm{MD}$, energy consumption will be reduced and better understood. The evolution of nontechnical drivers will heavily influence the relative attractiveness of both these energy resources and produced water desalination technologies.

\section{OUTLOOK}

Shale gas production is expanding in the United States and worldwide, despite controversy surrounding the environmental and public health implications of shale gas development and management of the resulting produced water. In the Marcellus shale region, and other shale plays worldwide with similar constraints, the anticipated combination of contracting internal reuse opportunities and economic, regulatory, and infrastructure drivers for external reuse will move the shale gas industry to desalinate produced water. Technological innovation is needed now to advance existing methods and develop new, energy-efficient technologies suitable for desalinating highsalinity produced water. Produced water desalination for external reuse is technologically feasible. Advancing this reuse in a safe and economical manner is the challenge for shale gas producers, engineers, researchers, and regulators.

We have reviewed MVC, MD, and FO as three suitable technologies for desalinating high-salinity produced water. Though they are technically suitable, the capital and operating costs of these technologies must be reduced to facilitate their

Table 1. Expected Use and Source of Electrical and Thermal Energies to Power the Desalination Technologies Reviewed ${ }^{a}$

\begin{tabular}{|c|c|c|c|c|}
\hline \multirow[b]{2}{*}{ technology } & \multicolumn{2}{|r|}{ energy use } & \multicolumn{2}{|c|}{ potential energy sources } \\
\hline & electrical & thermal (temperature) & most sustainable & conventional (to supplement) \\
\hline MVC & high & none-converted from electricity & $\begin{array}{l}\text { solar photovoltaic, electricity from high temperature } \\
\text { geothermal }\end{array}$ & $\begin{array}{l}\text { connection to grid or diesel-generated } \\
\text { electricity }\end{array}$ \\
\hline $\mathrm{MD}$ & low & $\begin{array}{l}\text { high }\left(60-80{ }^{\circ} \mathrm{C} \text {, higher flux if higher }\right. \\
\text { temperature })\end{array}$ & geothermal & $\begin{array}{l}\text { just-produced gas or diesel-generated } \\
\text { electricity }\end{array}$ \\
\hline FO & low & $\begin{array}{l}\text { high }\left(\geq 60{ }^{\circ} \mathrm{C} \text { for } \mathrm{NH}_{3}-\mathrm{CO}_{2} \text { draw }\right. \\
\text { solution })\end{array}$ & geothermal & $\begin{array}{l}\text { just-produced gas or diesel-generated } \\
\text { electricity }\end{array}$ \\
\hline
\end{tabular}

${ }^{a}$ Geothermal energy can be harvested from wells drilled for that specific and exclusive purpose or from the elevated temperature of the produced water. 
economical implementation. Capital costs may be reduced with modular and scalable systems that can be relocated or expanded to match the dynamic demand for produced water desalination. To this end, advancements in module design and operating parameters, especially for less-mature MD and FO technologies, may reduce costs. Reducing the extent of pretreatment required for these desalination technologies and increasing the efficiency of pretreatment technologies themselves could also reduce the capital costs of produced water desalination. Significant savings could be realized by improving the hydraulic fracturing process to decrease the volume or reduce the TDS concentration of produced water that must be desalinated.

Operating costs of a desalination technology can be reduced by lowering the specific energy consumption of the separation process (the amount of energy required to desalinate a unit volume of feed water) or by changing the type of energy employed in the separation. Using low-quality but inexpensive energy, such as geothermal energy, is one effective means of reducing the operating costs. Of the technologies we have reviewed, the specific energy consumption of MVC is the most well-established. MVC relies on relatively expensive, prime electrical energy to drive the thermal separation process, but improvements in the heat transfer coefficient of the evaporatorcondenser could reduce these energy requirements.

$\mathrm{MD}$ and $\mathrm{FO}$ are less established than MVC, but these technologies have the potential to harness the elevated temperature of produced water to help drive the separation. Using abundant, inexpensive geothermal energy can significantly reduce the energy costs of $\mathrm{MD}$ and $\mathrm{FO}$, thus increasing the economic incentive for their use. Materials and process improvements in $\mathrm{MD}$ and $\mathrm{FO}$ can further reduce the energy and operating costs of these technologies. Materials improvements include membranes that better reject draw solutes in FO and high-permeability, fouling-resistant membranes for both FO and MD. Reduced propensity for fouling translates to reduced operating costs through less extensive system pretreatment and cleaning requirements. Process improvements include integrating energy recovery devices to recover thermal energy from the elevated-temperature permeate stream in $\mathrm{MD}$ and from the volatilized draw solutes in FO to improve the overall energy efficiency. A recent pilot-scale demonstration of produced water desalination by FO is an important milestone toward full-scale implementation of the technology. Although $\mathrm{MD}$ has yet to be demonstrated at pilot- or full-scale, our understanding of the technology has progressed considerably from a recent flurry of research activity. A shift in the shale gas industry toward produced water desalination for external reuse industry may provide the incentives that lead to commercialization of MD technology.

Research in other areas can improve understanding of the economics of produced water management and help incentivize desalination for external reuse. More detailed assessments of the specific energy consumption of MVC, MD, and FO for desalinating high-salinity produced waters are needed to make direct comparisons between the technologies. Study of produced water management considerations and resulting practices in different shale plays, such as the Barnett shale and the Marcellus shale, can elucidate the specific drivers that initiate external reuse, and this information can inform regulators and policy makers. Considering the effect of reuse technologies on the overall water and energy balance of shale gas production will improve understanding of the potential savings and importance of this effort. More centralized and accessible sources of data for produced water quality, temperature, volumes, and management practices will facilitate study of these topics.

The horizontal drilling and hydraulic fracturing technologies that make shale gas production a feasible and market-changing activity are remarkable engineering achievements. The shale gas industry overcame many difficult technical challenges to accomplish the profitable recovery of gas where it was previously deemed inaccessible. Similarly, the technical challenges in desalinating shale gas produced water to enable its external reuse are surmountable, and MVC, MD, and FO represent promising technologies. In each shale play, economics, influenced by infrastructure and regulation, will determine how far these technologies must advance to accomplish widespread reuse.

\section{AUTHOR INFORMATION}

\section{Corresponding Author}

*E-mail: menachem.elimelech@yale.edu.

\section{Notes}

The authors declare no competing financial interest.

\section{ACKNOWLEDGMENTS}

This publication was developed under STAR Fellowship Assistance Agreement Nos. FP-91750001-0 and FP91733801-0 awarded by the U.S. Environmental Protection Agency (EPA) to D.L.S. and L.H.A.C., respectively. It has not been formally reviewed by EPA. The views expressed in this publication are solely those of the listed authors, and EPA does not endorse any products or commercial services mentioned in this publication.

\section{REFERENCES}

(1) United States Energy Information Administration. World Shale Gas Resources: An Initial Assessment of 14 Regions Outside the United States; United States Department of Energy: Washington, DC, April 2011; pp 1-365.

(2) International Energy Agency. World Energy Outlook 2011: Are We Entering a Golden Age of Gas?; International Energy Agency: Paris, France, 2011; pp 1-131.

(3) United States Energy Information Administration. Annual Energy Outlook; United States Department of Energy: Washington, DC, 2012.

(4) Helman, C. The Arithmetic of Shale Gas. Forbes June 22, 2012.

(5) MIT Energy Initiative. The Future of Natural Gas; Cambridge, MA, 2011.

(6) Osborn, S. G.; Vengosh, A.; Warner, N. R.; Jackson, R. B. Methane contamination of drinking water accompanying gas-well drilling and hydraulic fracturing. Proc. Natl. Acad. Sci. U.S.A. 2011, 108 (20), 8172-8176.

(7) Jackson, R. B.; Vengosh, A.; Darrah, T. H.; Warner, N. R.; Down, A.; Poreda, R. J.; Osborn, S. G.; Zhao, K.; Karr, J. D. Increased stray gas abundance in a subset of drinking water wells near Marcellus shale gas extraction. Proc. Natl. Acad. Sci. U.S.A. 2013, 110 (28), 1125011255.

(8) Olmstead, S. M.; Muehlenbachs, L. A.; Shih, J.-S.; Chu, Z.; Krupnick, A. J. Shale gas development impacts on surface water quality in Pennsylvania. Proc. Natl. Acad. Sci. U.S.A. 2013, 110 (13), 49624967.

(9) Howarth, R.; Santoro, R.; Ingraffea, A. Methane and the greenhouse-gas footprint of natural gas from shale formations. Clim. Change 2011, 106 (4), 679-690.

(10) Associated Press. NY fracking rules in limbo as deadline arrives; environmentalists urge opening health studies. The Washington Post, Feb 27, 2013. 
(11) Havard, K. Fracking in Maryland: Still under study. The Washington Post, Jan 17, 2013.

(12) Gregory, K. B.; Vidic, R. D.; Dzombak, D. A. Water Management Challenges Associated with the Production of Shale Gas by Hydraulic Fracturing. Elements 2011, 7 (3), 181-186.

(13) Vidic, R. D.; Brantley, S. L.; Vandenbossche, J. M.; Yoxtheimer, D.; Abad, J. D. Impact of Shale Gas Development on Regional Water Quality Science 2013, 340 (6134).

(14) Lutz, B. D.; Lewis, A. N.; Doyle, M. W. Generation, transport, and disposal of wastewater associated with Marcellus Shale gas development. Water Resour. Res. 2013, 49 (2), 647-656.

(15) United States Energy Information Administration. Review of Emerging Resources: U.S. Shale Gas and Shale Oil Plays; United States Department of Energy: Washington, DC, 2011.

(16) Clark, C. E.; Veil, J. A. Produced Water Volumes and Management Practices in the United States. United States Department of Energy, Argonne National Laboratory: Argonne, IL, 2009; p 59.

(17) Ground Water Protection Council, ALL Consulting. Modern Shale Gas Development in the United States: A Primer; United States Department of Energy, Office of Fossil Energy: Washington, D.C., 2009; p 96.

(18) Nicot, J.-P.; Scanlon, B. R. Water Use for Shale-Gas Production in Texas, U.S. Environ. Sci. Technol. 2012, 46 (6), 3580-3586.

(19) Murray, K. E. State-Scale Perspective on Water Use and Production Associated with Oil and Gas Operations, Oklahoma, U.S. Environ. Sci. Technol. 2013, 47 (9), 4918-4925.

(20) Mantell, M. E. Produced Water Reuse and Recycling Challenges and Opportunities Across Major Shale Plays. USEPA Technical Workshops for the Hydraulic Fracturing Study: Water Resources Management, Arlington, VA, May; United States Environmental Protection Agency Office of Research and Development, 2011.

(21) United States Government Accountability Office. Information on the Quantity, Quality, and Management of Water Produced during Oil and Gas Production; Washington, D.C., 2012.

(22) Interstate Oil and Gas Compact Commission, ALL Consulting. A Guide to Practical Management of Produced Water from Onshore Oil and Gas Operations in the United States; U.S. Department of Energy, National Petroleum Technology Office: Washington, D.C., 2006.

(23) Shariq, L. Uncertainties Associated with the Reuse of Treated Hydraulic Fracturing Wastewater for Crop Irrigation. Environ. Sci. Technol. 2013, 47 (6), 2435-2436.

(24) Marcellus Shale Advisory Commission. Report of the Governor's Marcellus Shale Advisory Commission; Commonwealth of Pennsylvania: Harrisburg, PA, July 22, 2011; p 136.

(25) Breit, G. N.; Otton, J. K. Produced Waters Database; United States Geological Survey: Reston, VA, May 29, 2002.

(26) Renner, R. Pennsylvania to regulate salt discharges. Environ. Sci. Technol. 2009, 43 (16), 6120-6120.

(27) Sapien, J. With Natural Gas Drilling Boom, Pennsylvania Faces Flood of Wastewater. Sci. Am. October 5, 2009.

(28) Wastewater Treatment Requirements. Pennsylvania Code, Section 10, Title 25, Chapter 95, 2010.

(29) McCurdy, R. Underground Injection Wells for Produced Water Disposal. USEPA Technical Workshops for the Hydraulic Fracturing Study: Water Resources Management, Arlington, VA, May; United States Environmental Protection Agency, Office of Research and Development, 2011.

(30) Ohio Department of Natural Resources. Preliminary Report on the Northstar 1 Class II Injection Well and the Seismic Events in the Youngstown, Ohio, Area; Ohio Department of Natural Resources: Columbus, OH, 2012.

(31) Fakhru'l-Razi, A.; Pendashteh, A.; Abdullah, L. C.; Biak, D. R. A.; Madaeni, S. S.; Abidin, Z. Z. Review of technologies for oil and gas produced water treatment. J. Hazard. Mater. 2009, 170 (2-3), 530551.

(32) Drewes, J. E. An Integrated Framework for Treatment and Management of Produced Water: Technical Assessment of Produced Water Treatment Technologies: The Colorado School of Mines: Golden, CO, 2009; p 158.
(33) Haluszczak, L. O.; Rose, A. W.; Kump, L. R. Geochemical evaluation of flowback brine from Marcellus gas wells in Pennsylvania, USA. Appl. Geochem. 2013, 28, 55-61.

(34) Johnson, B.; Kanagy, L.; Rodgers, J.; Castle, J. Chemical, Physical, and Risk Characterization of Natural Gas Storage Produced Waters. Water, Air, Soil Pollut. 2008, 191 (1), 33-54.

(35) Benko, K. L.; Drewes, J. E. Produced Water in the Western United States: Geographical Distribution, Occurrence, and Composition. Environ. Eng. Sci. 2008, 25 (2), 7.

(36) Greenlee, L. F.; Lawler, D. F.; Freeman, B. D.; Marrot, B.; Moulin, P. Reverse osmosis desalination: Water sources, technology, and today's challenges. Water Res. 2009, 43 (9), 2317-2348.

(37) Fritzmann, C.; Löwenberg, J.; Wintgens, T.; Melin, T. State-ofthe-art of reverse osmosis desalination. Desalination 2007, 216 (1-3), $1-76$.

(38) Ghaffour, N.; Missimer, T. M.; Amy, G. L. Technical review and evaluation of the economics of water desalination: Current and future challenges for better water supply sustainability. Desalination 2013, 309, 197-207.

(39) Koren, A.; Nadav, N. Mechanical vapour compression to treat oil field produced water. Desalination 1994, 98 (1-3), 41-48.

(40) Veza, J. M. Mechanical Vapor Compression Desalination Plants - a Case-Study. Desalination 1995, 101 (1), 1-10.

(41) Zimerman, Z. Development of Large-Capacity High-Efficiency Mechanical Vapor Compression (Mvc) Units. Desalination 1994, 96 (1-3), 51-58.

(42) Mistry, K. H.; McGovern, R. K.; Thiel, G. P.; Summers, E. K.; Zubair, S. M.; Lienhard, J. H. Entropy Generation Analysis of Desalination Technologies. Entropy 2011, 13 (10), 1829-1864.

(43) Heinz, W. F. Is a Paradigm Shift in Produced Water Treatment Technology Occurring at SAGD Facilities? In Canadian International Petroleum Conference (CIPC), Calgary, June 12-14, 2007.

(44) Xu, T.; Pruess, K. Thermophysical properties of sodium nitrate and sodium chloride solutions and their effects on fluid flow in unsaturated media; Lawrence Berkeley National Laboratory: Berkeley, CA, 2001.

(45) Darwish, M. A. Thermal analysis of vapor compression desalination system. Desalination 1988, 69 (3), 275-295.

(46) Bahar, R.; Hawlader, M. N. A.; Woei, L. S. Performance evaluation of a mechanical vapor compression desalination system. Desalination 2004, 166 (1-3), 123-127.

(47) Langer, H.; Offermann, H. On the solubility of sodium chloride in water. J. Cryst. Growth 1982, 60 (2), 389-392.

(48) Khazhsetovich, K. R.; Fedorovich, M. B.; Antonovich, R. B.; Ivanovna, M. L.; Gennadievich, A. E.; Vladimirovna, F. O.; Grigorievich, N. E.; Pavlovich, V. V.; Ilich, G. S.; Davydovich, C. V.; Ekhilievich, S. M.; Sergeevich, D. A.; Nikolaevich, D. A.; Saferbievich, B. K.; Anatolievich, R. J. Method for complex processing of sea-water. United States Patent 5,814,224, 1998.

(49) Lipnizki, F.; Hausmanns, S.; Ten, P.-K.; Field, R. W.; Laufenberg, G. Organophilic pervaporation: prospects and performance. Chem. Eng. J. 1999, 73 (2), 113-129.

(50) Lokiec, F.; Ophir, A. The Mechanical Vapor Compression: 38 Years of Experience. IDA World Congress, Maspalomas, Gran Canaria, Spain, October 21-26, 2007.

(51) Al-Juwayhel, F.; El-Dessouky, H.; Ettouney, H. Analysis of single-effect evaporator desalination systems combined with vapor compression heat pumps. Desalination 1997, 114 (3), 253-275.

(52) Lukic, N.; Diezel, L. L.; Froba, A. P.; Leipertz, A. Economical aspects of the improvement of a mechanical vapour compression desalination plant by dropwise condensation. Desalination 2010, 264 (1-2), 173-178.

(53) Lawson, K. W.; Lloyd, D. R. Membrane distillation. J. Membr. Sci. 1997, 124 (1), 1-25.

(54) Alklaibi, A. M.; Lior, N. Membrane-distillation desalination: status and potential. Desalination 2005, 171 (2), 111-131.

(55) Curcio, E.; Drioli, E. Membrane distillation and related operations - A review. Sep. Purif. Rev. 2005, 34 (1), 35-86. 
(56) El-Bourawi, M. S.; Ding, Z.; Ma, R.; Khayet, M. A framework for better understanding membrane distillation separation process. J. Membr. Sci. 2006, 285 (1-2), 4-29.

(57) Khayet, M.; Matsuura, T. Membrane distillation: principles and applications; Elsevier: Oxford, 2011.

(58) Alkhudhiri, A.; Darwish, N.; Hilal, N. Membrane distillation: A comprehensive review. Desalination 2012, 287, 2-18.

(59) Lawson, K. W.; Lloyd, D. R. Membrane distillation. II. Direct contact MD. J. Membr. Sci. 1996, 120 (1), 123-133.

(60) Al-Obaidani, S.; Curcio, E.; Macedonio, F.; Di Profio, G.; AiHinai, H.; Drioli, E. Potential of membrane distillation in seawater desalination: Thermal efficiency, sensitivity study and cost estimation. J. Membr. Sci. 2008, 323 (1), 85-98.

(61) Criscuoli, A.; Carnevale, M. C.; Drioli, E. Evaluation of energy requirements in membrane distillation. Chem. Eng. Process. 2008, 47 (7), 1098-1105.

(62) Meindersma, G. W.; Guijt, C. M.; de Haan, A. B. Desalination and water recycling by air gap membrane distillation. Desalination 2006, 187 (1-3), 291-301.

(63) Cath, T. Y.; Adams, V. D.; Childress, A. E. Experimental study of desalination using direct contact membrane distillation: a new approach to flux enhancement. J. Membr. Sci. 2004, 228 (1), 5-16.

(64) Singh, D.; Sirkar, K. K. Desalination of brine and produced water by direct contact membrane distillation at high temperatures and pressures. J. Membr. Sci. 2012, 389, 380-388.

(65) Alkhudhiri, A.; Darwish, N.; Hilal, N. Produced water treatment: Application of Air Gap Membrane Distillation. Desalination 2013, 309, $46-51$.

(66) Gryta, M. Long-term performance of membrane distillation process. J. Membr. Sci. 2005, 265 (1-2), 153-159.

(67) Gryta, M. Fouling in direct contact membrane distillation process. J. Membr. Sci. 2008, 325 (1), 383-394.

(68) Martinetti, C. R.; Childress, A. E.; Cath, T. Y. High recovery of concentrated RO brines using forward osmosis and membrane distillation. J. Membr. Sci. 2009, 331 (1-2), 31-39.

(69) Gryta, M. The assessment of microorganism growth in the membrane distillation system. Desalination 2002, 142 (1), 79-88.

(70) Hsu, S. T.; Cheng, K. T.; Chiou, J. S. Seawater desalination by direct contact membrane distillation. Desalination 2002, 143 (3), 279287.

(71) Gryta, M.; Tomaszewska, M.; Karakulski, K. Wastewater treatment by membrane distillation. Desalination 2006, 198 (1-3), 67-73.

(72) Gryta, M. Chemical pretreatment of feed water for membrane distillation. Chem. Pap. 2008, 62 (1), 100-105.

(73) Ray, J. P.; Engelhardt, F. R. Produced water: technological/ environmental issues and solutions; Plenum Press: New York, 1992; $\mathrm{p}$ 616.

(74) Fane, A. G.; Schofield, R. W.; Fell, C. J. D. The efficient use of energy in membrane distillation. Desalination 1987, 64, 231-243.

(75) Kurokawa, H.; Sawa, T. Heat recovery characteristics of membrane distillation. Heat Transfer-Japn. Res. 1996, 25 (3), 135150.

(76) Cath, T. Y.; Childress, A. E.; Elimelech, M. Forward osmosis: Principles, applications, and recent developments. J. Membr. Sci. 2006, 281 (1-2), 70-87.

(77) McCutcheon, J. R.; McGinnis, R. L.; Elimelech, M. A novel ammonia-carbon dioxide forward (direct) osmosis desalination process. Desalination 2005, 174 (1), 1-11.

(78) Lee, S.; Boo, C.; Elimelech, M.; Hong, S. Comparison of fouling behavior in forward osmosis (FO) and reverse osmosis (RO). J. Membr. Sci. 2010, 365 (1-2), 34-39.

(79) Mi, B. X.; Elimelech, M. Organic fouling of forward osmosis membranes: Fouling reversibility and cleaning without chemical reagents. J. Membr. Sci. 2010, 348 (1-2), 337-345.

(80) Tiraferri, A.; Kang, Y.; Giannelis, E. P.; Elimelech, M. Superhydrophilic Thin-Film Composite Forward Osmosis Membranes for Organic Fouling Control: Fouling Behavior and Antifouling Mechanisms. Environ. Sci. Technol. 2012, 46 (20), 11135-11144.
(81) Ling, M. M.; Chung, T. S.; Lu, X. M. Facile synthesis of thermosensitive magnetic nanoparticles as "smart" draw solutes in forward osmosis. Chem. Commun. 2011, 47 (38), 10788-10790.

(82) Li, D.; Zhang, X. Y.; Simon, G. P.; Wang, H. T. Forward osmosis desalination using polymer hydrogels as a draw agent: Influence of draw agent, feed solution and membrane on process performance. Water Res. 2013, 47 (1), 209-215.

(83) Ge, Q. C.; Su, J. C.; Amy, G. L.; Chung, T. S. Exploration of polyelectrolytes as draw solutes in forward osmosis processes. Water Res. 2012, 46 (4), 1318-1326.

(84) Shaffer, D. L.; Yip, N. Y.; Gilron, J.; Elimelech, M. Seawater desalination for agriculture by integrated forward and reverse osmosis: Improved product water quality for potentially less energy. J. Membr. Sci. 2012, 415, 1-8.

(85) Holloway, R. W.; Childress, A. E.; Dennett, K. E.; Cath, T. Y. Forward osmosis for concentration of anaerobic digester centrate. Water Res. 2007, 41 (17), 4005-4014.

(86) Hoover, L. A.; Phillip, W. A.; Tiraferri, A.; Yip, N. Y.; Elimelech, M. Forward with Osmosis: Emerging Applications for Greater Sustainability. Environ. Sci. Technol. 2011, 45 (23), 9824-9830.

(87) Hickenbottom, K. L.; Hancock, N. T.; Hutchings, N. R.; Appleton, E. W.; Beaudry, E. G.; Xu, P.; Cath, T. Y. Forward osmosis treatment of drilling mud and fracturing wastewater from oil and gas operations. Desalination 2012, 312, 60-66.

(88) McGinnis, R. L.; Elimelech, M. Global Challenges in Energy and Water Supply: The Promise of Engineered Osmosis. Environ. Sci. Technol. 2008, 42 (23), 8625-8629.

(89) McCutcheon, J. R.; McGinnis, R. L.; Elimelech, M. Desalination by ammonia-carbon dioxide forward osmosis: Influence of draw and feed solution concentrations on process performance. J. Membr. Sci. 2006, 278 (1-2), 114-123.

(90) Elimelech, M.; Phillip, W. A. The Future of Seawater Desalination: Energy, Technology, and the Environment. Science 2011, 333 (6043), 712-717.

(91) Kim, Y. C.; Park, S. J. Experimental Study of a 4040 SpiralWound Forward-Osmosis Membrane Module. Environ. Sci. Technol. 2011, 45 (18), 7737-7745.

(92) McGinnis, R. L.; Hancock, N. T.; Nowosielski-Slepowron, M. S.; McGurgan, G. D. Pilot demonstration of the NH3/CO2 forward osmosis desalination process on high salinity brines. Desalination 2012, $312,67-74$

(93) Yip, N. Y.; Tiraferri, A.; Phillip, W. A.; Schiffman, J. D.; Elimelech, M. High Performance Thin-Film Composite Forward Osmosis Membrane. Environ. Sci. Technol. 2010, 44 (10), 3812-3818.

(94) Zhao, S.; Zou, L.; Tang, C. Y.; Mulcahy, D. Recent developments in forward osmosis: Opportunities and challenges. J. Membr. Sci. 2012, 396, 1-21.

(95) Xiao, D.; Li, W.; Chou, S.; Wang, R.; Tang, C. Y. A modeling investigation on optimizing the design of forward osmosis hollow fiber modules. J. Membr. Sci. 2012, 392-393, 76-87.

(96) McGinnis, R. L.; Elimelech, M. Energy requirements of ammonia-carbon dioxide forward osmosis desalination. Desalination 2007, 207 (1-3), 370-382.

(97) Ikeda, M.; Miyamoto, M. Forward Osmosis Device, and Forward Osmosis Method. Japanese Patent JP2012091166, 2012.

(98) Wilson, A. D.; Stewart, F.; Stone, M. L. Methods and Systems for Treating Liquids Using Switchable Solvents. United States Patent 20130048561, 2013.

(99) Stone, M. L.; Rae, C.; Stewart, F. F.; Wilson, A. D. Switchable polarity solvents as draw solutes for forward osmosis. Desalination 2013, 312, 124-129.

(100) Koros, W. J. Evolving beyond the thermal age of separation processes: Membranes can lead the way. AIChE J. 2004, 50 (10), 2326-2334.

(101) Wigley, T. L. Coal to gas: the influence of methane leakage. Clim. Change 2011, 108 (3), 601-608.

(102) Howarth, R. W.; Ingraffea, A.; Engelder, T. Natural gas: Should fracking stop? Nature 2011, 477 (7364), 271-275. 
(103) Jenner, S.; Lamadrid, A. J. Shale gas vs. coal: Policy implications from environmental impact comparisons of shale gas, conventional gas, and coal on air, water, and land in the United States. Energy Policy 2013, 53, 442-453.

(104) Adams, M. B.; Edwards, P. J.; Ford, W. M.; Johnson, J. B.; Schuler, T. M.; Thomas-Van Gundy, M.; Wood, F. Effects of development of a natural gas well and associated pipeline on the natural and scientific resources of the Fernow Experimental Forest. United States Forest Service: Newtown Square, PA, 2011.

(105) National Renewable Energy Laboratory. Federal Energy Management Program Maps; Golden, CO, 2013.

(106) Blackwell, D.; Richards, M.; Frone, Z.; Batir, J.; Ruzo, A.; Dingwall, R.; Williams, M. Temperature at depth maps for the conterminous US and geothermal resource estimates. Geothermal Resources Council Transactions; Geothermal Resources Council: Davis, CA, 2011; Vol. 35; available from http://geothermal.org.

(107) Tester, J. W.; Anderson, B.; Batchelor, A.; Blackwell, D.; DiPippo, R.; Drake, E.; Garnish, J.; Livesay, B.; Moore, M.; Nichols, K. The future of geothermal energy; Massachusetts Institute of Technology: Cambridge, MA, 2006.

(108) Driscoll, F. G. Groundwater and Wells, 2nd ed.; Johnson Division: St. Paul, MN, 1986.

(109) United States Energy Information Administration. Maps: Exploration, Resources, Reserves, and Production. http://www.eia. gov/pub/oil_gas/natural_gas/analysis_publications/maps/maps.htm (accessed March 21, 2013). 